\title{
IN VITRO STUDY OF ANTI-INFLAMMATORY AND ANTIOXIDANT ACTIVITY OF SOME MEDICINAL PLANTS AND THEIR INTERRELATIONSHIP
}

\author{
SHUBHI RASTOGI, MOHAMMED SHARIQ IQBAL*, DEEPAK OHRI
}

Amity Research Cell, Amity University Uttar Pradesh, Lucknow Campus, India. Email: msiqbal@lko.amity.edu

Received: 10 November 2017, Revised and Accepted: 01 January 2018

ABSTRACT

Objective: The objective of the present work is to study the in vitro anti-inflammatory and antioxidant activity of medicinal plants. The extent and correlation between anti-inflammatory and antioxidant activity have been studied.

Method: Methanolic and aqueous extracts of five medicinal plants, namely, Ficus racemosa, Aloe vera, Cannabis sativa, Datura stramonium, and Calotropis gigantean have been taken for in vitro anti-inflammatory and total antioxidant activity.

Result: The study showed that the inhibition of protein (albumin) denaturation was maximum in aqueous extract of $A$. vera with $97.55 \pm 1.45 \%$. Proteinase inhibitory action of different plant extracts showed significant action and was found to be maximum in aqueous extract of $D$. stramonium with $87.89 \pm 2.58 \%$. Heat-induced hemolysis showed that maximum inhibition was with aqueous extract of $F$. racemosa with $90.72 \pm 3.33 \%$. When hypotonicity-induced hemolysis activity was done it was found maximum in methanolic extract of C. gigantea with $90.58 \pm 3.04 \%$. Anti-lipoxygenase activity was found maximum in methanolic extract of $F$. racemosa with $94.05 \pm 4.24 \%$. When total antioxidant activity was done, it was found highest in F. racemosa (4.38 $\pm 0.546 \mathrm{mM}$ equivalent of ascorbic acid/g tissue).

Conclusion: An overall strong positive correlation between anti-inflammatory and antioxidant activity was observed, indicating that antioxidant activity of the plant species studied might be responsible for their anti-inflammatory property. Further work needs to be undertaken to fully elucidate the antioxidants responsible for anti-inflammatory action and to develop better herbal drug formulations.

Keywords: Anti-inflammatory, Antioxidant, Hemolysis, Lipoxygenase, Medicinal plants.

(C) 2018 The Authors. Published by Innovare Academic Sciences Pvt Ltd. This is an open access article under the CC BY license (http://creativecommons. org/licenses/by/4. 0/) DOI: http://dx.doi.org/10.22159/ajpcr.2018.v11i4.23583

\section{INTRODUCTION}

A free radical is a molecule or atom that carries one or more unpaired electrons and is able to exist independently [1]. Free radicals are short-lived, highly reactive, and unstable as they possess odd number of electrons. Subsequently, to obtain stability, free radicals can react quickly with other elements trying to catch the required electron. Meanwhile, the confronted molecule can become a free radical by losing its electron and start a chain reaction cascade causing damage to the living cell [2]. It was observed that most of the reactive oxygen species are produced in cells through the mitochondrial respiratory chain [1,2]. Lipids and proteins are essential targets for oxidative attack and alteration of these molecules can enhance the mutagenesis process $[3,4]$. In the inflammatory response, leukocytes and mast cells are present in the damaged areas which are responsible for "respiratory burst" as a result of further uptake of oxygen and therefore boost the release of reactive oxygen species at the damaged area $[3,4]$. Although inflammatory cells produce more soluble inflammatory mediators such as arachidonic acid, cytokines, and chemokines, that act through end to end at active inflammatory cells in the area of infection and discharge more reactive species. These indispensable markers can rouse signal transduction flows in addition to modifications in transcription factors, such as nuclear factor of activated $\mathrm{T}$ cells, signal transducer and activator of transcription 3, nuclear factor kappa B, activator protein-1, NF-E2 related factor-2, and hypoxia-inducible factor- $1 \alpha$, that mediates cellular stress reactions. Initiation of cyclooxygenase-2, inducibility of nitric oxide synthase, and high expression of inflammatory cytokines, including tumor necrosis factor- $\beta$, interleukin- $1 \beta$, (IL-6), and chemokines, in addition to changes in the expression of specific microRNAs have also been revealed to possess oxidative stress-induced inflammation $[5,6]$. This inflammatory/oxidative environment activate harmful sphere, that can lead to damaging of healthy stromal cells and adjoining epithelial cells, which may cause carcinogenesis, if delayed $[2,5]$. The present study is aimed to explain the mode of action and relationship between antioxidant and anti-inflammatory activity of various medicinal plants to develop herbal anti-inflammatory drugs.

\section{METHODS}

Plant samples of Ficus racemosa, Aloe vera, Cannabis sativa, Datura stramonium, and Calotropis gigantea were collected in fresh condition from the herbal garden at Amity University, Uttar Pradesh, Lucknow, India. The plant material was thoroughly washed with tap water followed by distilled water. For drying washed tissues were dried on blotting paper and spread out at room temperature in the shade. Shade-dried materials were ground to fine powder with tissue blender. The extracts were prepared according to Tiwari et al. [7] with few modifications. Two types of solvents, namely, methanol and water were used to prepare a variety of extracts from the plant samples. The extracts were filtered through Whatman filter paper and evaporated till dryness. The dried extracts were dissolved in $1 \mathrm{mg} / \mathrm{ml}$ stock solution with methanol and water, respectively, filtered with $0.45 \mu \mathrm{m}$ syringe filter for analysis. The stock solutions were diluted to different concentrations of $500 \mu \mathrm{g} / \mathrm{ml}, 400 \mu \mathrm{g} / \mathrm{ml}, 300 \mu \mathrm{g} / \mathrm{ml}, 200 \mu \mathrm{g} / \mathrm{ml}$, and $100 \mu \mathrm{g} / \mathrm{ml}$ for further analysis.

\section{Assessment of in vitro anti-inflammatory activity Inhibition of albumin denaturation}

The anti-inflammatory activity of methanolic and aqueous extracts of $F$. racemosa, A. vera, C. sativa, D. stramonium, and C. gigantean were studied 
according to the protocol of Mizushima et al. and Sakat et al. [8,9] with some modifications. Inhibition of albumin denaturation was done according to the protocol. The reaction mixture consists of an equal volume of test extracts of different concentrations $(100-500 \mu \mathrm{g} / \mathrm{ml})$ and $1 \%$ aqueous solution of bovine albumin (Fraction $\mathrm{V}$ ). The $\mathrm{pH}$ of the reaction mixture was adjusted using a small amount of $1 \mathrm{~N} \mathrm{HCl}$. The sample extracts were incubated at $37^{\circ} \mathrm{C}$ for $20 \mathrm{~min}$ and then heated to $51^{\circ} \mathrm{C}$ for $20 \mathrm{~min}$. The absorbance was measured after cooling the samples at room temperature. The turbidity formed was measured at $660 \mathrm{~nm}$ using ultraviolet (UV)-visible spectrophotometer (Model: Shimadzu UV-1800). The percentage inhibition of protein denaturation was calculated as follows:

\%inhibition $=\frac{\text { Abs control }- \text { Abs sample }}{\text { Abs control }} \times 100$

\section{Antiproteinase action}

The activity was performed by the protocol of Sakat et al. and Oyedepo et al. $[9,10]$ with some modifications. The reaction mixture $(2 \mathrm{ml})$ containing $0.001 \%$ trypsin, $1 \mathrm{ml}$ of $1 \mathrm{mM}$ Tris $\mathrm{HCl}$ buffer (pH 7.4) and $1 \mathrm{ml}$ test sample of different concentrations (100-500 $\mu \mathrm{g} / \mathrm{ml}$ ). The mixture was incubated at $37^{\circ} \mathrm{C}$ for $5 \mathrm{~min}$ and then $1 \mathrm{ml}$ of $0.02 \%(\mathrm{w} / \mathrm{v})$ casein was added. The mixture was incubated for an additional $20 \mathrm{~min}$ at $37^{\circ} \mathrm{C} .2 \mathrm{ml}$ of $2 \%$ perchloric acid was added to arrest the reaction. Cloudy suspension was centrifuged and the absorbance of the supernatant was read at $210 \mathrm{~nm}$ against buffer as blank. The percentage inhibition of proteinase inhibitory activity was calculated.

$$
\text { \%inhibition }=\frac{\text { Abs control }- \text { Abs sample }}{\text { Abs control }} \times 100
$$

\section{Membrane stabilization}

Preparation of red blood cells (RBCs) suspension [9,11]. The blood was obtained from a healthy human volunteer who had not taken any nonsteroidal anti-inflammatory drugs for 2 weeks before the experiment. The blood sample was centrifuged at $3000 \mathrm{rpm}$ for $10 \mathrm{~min}$ and was washed 3 times with equal volume of normal saline. The amount of blood was measured and re-constituted as $10 \% \mathrm{v} / \mathrm{v}$ in normal saline suspension.

\section{Heat-induced hemolysis}

The activity was done according to the protocol of Sakat et al. and Shinde et al. [9,12] with some modifications. The reaction mixture $(2 \mathrm{ml})$ comprised $1 \mathrm{ml}$ test sample at different concentrations (100$500 \mu \mathrm{g} / \mathrm{ml}$ ) and $10 \%$ RBCs suspension (1 ml). For control, only saline was added to the test tube. Aspirin as a reference was used. The reaction mixture was incubated in water bath for $30 \mathrm{~min}$, at $56^{\circ} \mathrm{C}$. The reaction was stopped by cooling the reaction mixture under running tap water. The reaction mixture was then centrifuged at $2500 \mathrm{rpm}$ for $5 \mathrm{~min}$. The supernatant collected was used to take absorbance at $560 \mathrm{~nm}$. The experiment was performed in triplicates. The percentage inhibition of hemolysis was calculated as follows:

$$
\% \text { inhibition }=\frac{\text { Abs control }- \text { Abs sample }}{\text { Abs control }} \times 100
$$

\section{Hypotonicity-induced hemolysis}

Hypotonicity-induced hemolysis was done according to the protocol of Azeem et al. [13] with some modifications. Extracts of different concentration (100-500 $\mu \mathrm{g} / \mathrm{ml}$ ), reference sample (diclofenac sodium $100 \mu \mathrm{g} / \mathrm{ml}$ ), and control were individually mixed with phosphate buffer pH $7.0(1 \mathrm{ml})$, hyposaline $(2 \mathrm{ml})$, and RBC suspension $(0.5 \mathrm{ml})$. The reaction mixtures were incubated at $37^{\circ} \mathrm{C}$ for $30 \mathrm{~min}$. It was then centrifuged at $3000 \mathrm{rpm}$. The supernatant was transferred, and absorbance was taken at $560 \mathrm{~nm}$. The percentage hemolysis was calculated by assuming control as $100 \%$.
$\%$ protection $=100-\frac{\text { OD sample }}{\text { OD control }} \times 100$

\section{Anti-lipoxygenase activity}

Anti-lipoxygenase activity was studied with minor modifications, using linoleic acid as substrate and lipoxidase as an enzyme [12]. Test samples were dissolved in $2 \mathrm{M}$ borate buffer $\mathrm{pH} 9.0(0.25 \mathrm{ml})$ and $(0.25 \mathrm{ml})$ lipoxidase enzyme solution $(20,000 \mathrm{U} / \mathrm{ml})$. The reaction mixture was incubated for $5 \mathrm{~min}$ at $25^{\circ} \mathrm{C}$. Then, $0.6 \mathrm{mM}$ lenoleic acid solution $(1.0 \mathrm{ml})$ was added. The reaction mixture was vortexed, and absorbance was measured at $234 \mathrm{~nm}$. Indomethacin as a reference was used. The percent inhibition was calculated from the following equation:

$\%$ inhibition $=\frac{\text { Abs control }- \text { Abs sample }}{\text { Abs control }} \times 100$

\section{Total antioxidant activity}

Total antioxidant activity was assayed by the protocol of Cacig et al. and Iqbal et al. $[14,15]$ with some modifications. $1.0 \mathrm{~g}$ of tissue was homogenized in $4 \mathrm{ml}$ of double distilled water and incubated for $24 \mathrm{~h}$ at $4^{\circ} \mathrm{C}$. It was then filtered twice with Whatman No. 1 filter paper and the filtrate collected was stored at $4^{\circ} \mathrm{C}$. Suitable amount of sample was taken in a $3 \mathrm{ml}$ glass cuvette containing the oxidative mixture of $0.18 \mathrm{ml}$ potassium permanganate $(0.01 \mathrm{M}) ; 0.42 \mathrm{ml}$ sulfuric acid (2M) and distilled water to make up volume up to $3 \mathrm{ml}$. The decrease in absorbance was measured at $535 \mathrm{~nm}$. Ascorbic acid was taken as standard. Readings were taken in triplicaste and the mean activity ( \pm standard deviation) was calculated and used for plotting the graph.

To quantitatively compare the antioxidant activities, the following formula was used:

$$
\mathrm{A} 50=\mathrm{t} \text { standard } \cdot \frac{\text { Cstandard }}{\mathrm{t} \text { plant sample }} \cdot \frac{\mathrm{V} \text { standard }}{\mathrm{m} \text { plant }} \cdot \frac{\text { V extract }}{\mathrm{V} \text { plant sample }}
$$

Where:

A50 - antioxidant activity expressed, reproduced in the time until the sample makes a decrease of the oxidizing agent (potassium permanganate) concentration up to one half, compared against a standard (ascorbic acid) (mM equivalent standard/gram plant). t plant sample - the time until the sample induces a decrease of the potassium permanganate concentration up to one half (min).

tstandard - the time till the standard (ascorbic acid) induces a decline of the potassium permanganate concentration up to one half ( $\mathrm{min}$ ) ( 0.66 min as seen in standard curve).

C standard - standard (ascorbic acid) concentration $(\mathrm{mM} / \mathrm{mL}$ ) $(0.01 \mathrm{mM} / \mathrm{mL})$.

$\mathrm{m}$ plant - weight (gram) of the plant sample subjected to extraction $(1 \mathrm{~g})$.

$\mathrm{V}$ plant sample - volume of the plant extract subjected to the analysis $(0.1 \mathrm{ml})$.

V standard - volume of the standard subjected to the analysis $(1 \mathrm{ml})$. $V$ extract - volume $(\mathrm{mL})$ of the obtained extract $(4 \mathrm{ml})$.

\section{Statistical analysis}

Results are expressed as mean \pm standard deviation. The difference among experimental sets was compared by two-way analysis of variance (ANOVA). Correlation was established between total antioxidant and different anti-inflammatory activities.

\section{RESULTS AND DISCUSSION}

There are many methods to estimate the anti-inflammatory action of drugs. At present, a comparative study has been done on a methanolic and aqueous extract of five different medicinal plants species for anti- 
inflammatory activity. Primarily the inhibition of protein (albumin) denaturation was studied and was found the maximum in aqueous extract of $A$. vera with $97.55 \pm 1.45 \%$, while minimum in aqueous extract of $C$. gigantea with $47.80 \pm 1.75 \%$. Results are represented in Fig. 1. In a similar study by Reshma et al. [16] plant extracts of Aegle marmelos and Ocimum sanctum were effective in inhibiting heat-induced albumin denaturation and were observed $95.64 \mu \mathrm{g} / \mathrm{mL}$ and $42.17 \mu \mathrm{g} / \mathrm{mL}$, respectively. In a comparative study, $A$. vera was found to be marginally more active in inhibition of protein (albumin) denaturation than Citrus sinensis. It may be due to the higher flavonoids contents of $A$. vera [17].

The proteinase inhibitory action of different plant extract showed significant action. It was found the maximum in aqueous extract of $D$. stramonium with $87.89 \pm 2.58 \%$, and minimum in aqueous extract of $F$. racemosa with $2.95 \pm 0.57 \%$ (Fig. 2). Similarly, Duraid [18] found D. stramonium as a potent anti-inflammatory plant. Studies on other plants also revealed significant proteinase inhibitory action. The aqueous extract of leaves of $A$. marmelos and $O$. sanctum exhibited significant antiproteinase activity. Maximum inhibition was observed in A. marmelos leaf extract. A. marmelos and $O$. sanctum were observed as $74.45 \mu \mathrm{g} / \mathrm{mL}$ and $49.70 \mu \mathrm{g} / \mathrm{mL}$, respectively [16]. It was earlier investigated that leukocyte proteinase plays a significant part in the enhancement of tissue damage during inflammatory reactions and substantial level of defense was delivered by proteinase inhibitors [19].

The extract was also effective in reducing the heat-induced hemolysis at various concentrations. The results showed that maximum inhibition was with aqueous extract of $F$. racemosa with $90.72 \pm 3.33 \%$ while minimum in methanolic extract of $C$. sativa with $2.94 \pm 0.48 \%$ (Fig. 3). All the extracts were effectively inhibiting the heat-induced hemolysis involving stabilization of RBC membrane. Heat-induced hemolysis of HRBC by methanolic extract of Ficus virens is effective with maximum inhibition of $64 \%$ at $200 \mu \mathrm{g} / \mathrm{ml}$ [20]. A similar study by Govindappa et al. [21] also showed effective inhibition of heat-induced hemolysis by ethanolic extract of Wedelia trilobata. The maximum inhibitions were $78.11 \%$ from leaf extract followed by the stem $(74.17 \%)$ and flower (58.74\%).

The hypotonicity-induced hemolysis activity was found to be maximum in methanolic extract of $C$. gigantea with $90.58 \pm 3.04 \%$, while minimum in aqueous extract of $C$. sativa $8.29 \pm 0.88 \%$ (Fig. 4). Saumya et al. [22] reported C. gigantea to possess anti-inflammatory activity on Wistar
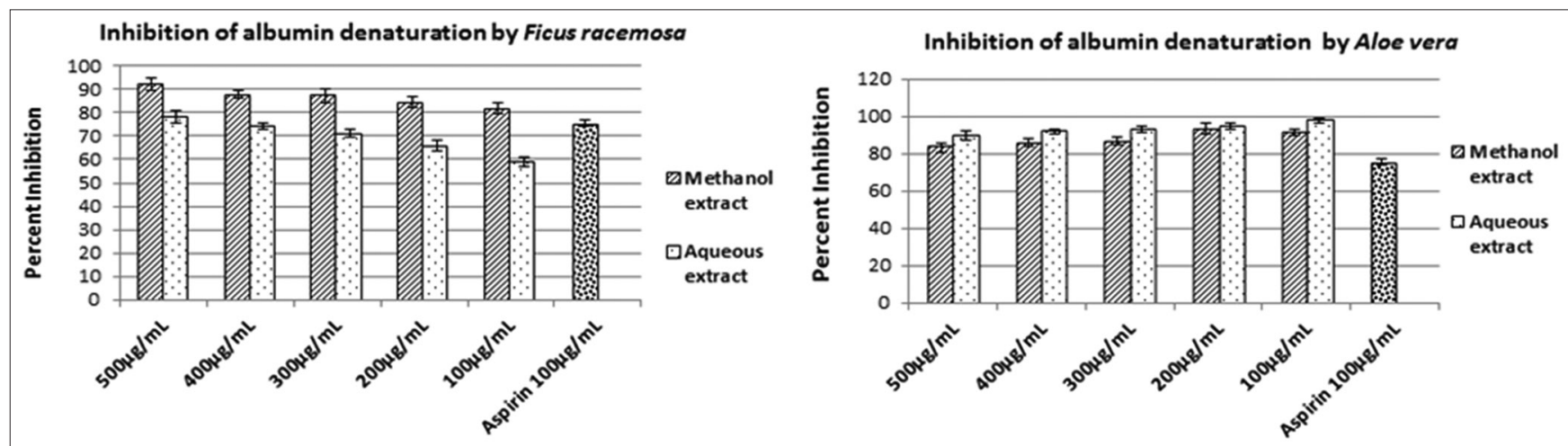

Inhibition of albumin denaturation by Cannabis sativa

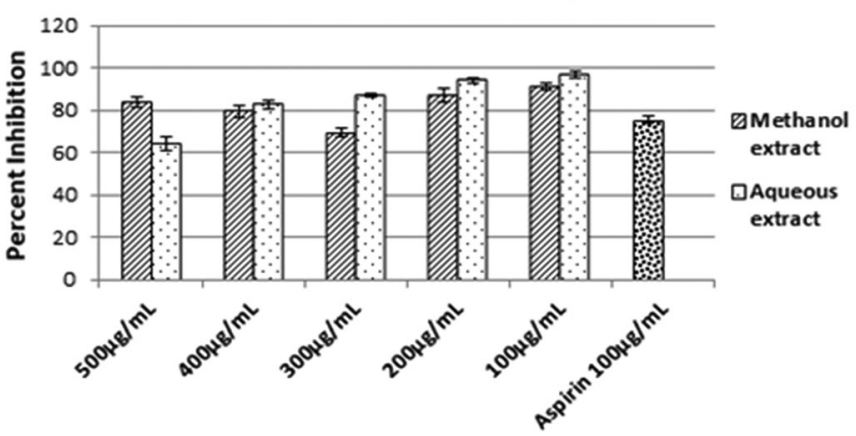

Inhibition of albumin denaturation by Datura stramonium

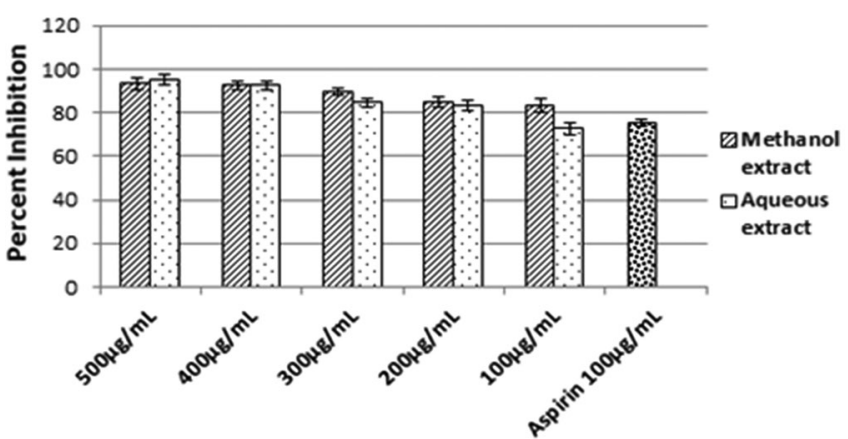

Inhibition of albumin denaturation by Calotropis gigantea

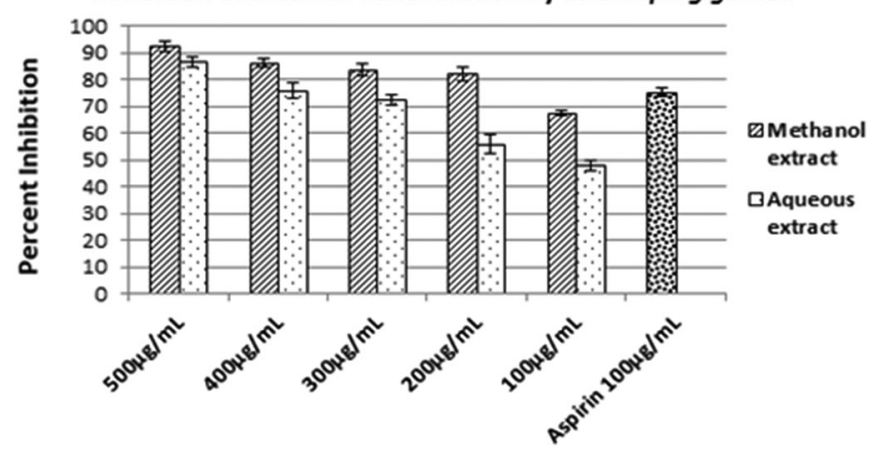

Fig. 1: Inhibition of protein (albumin) denaturation by different methanolic and aqueous extracts of medicinal plants. Two-way analysis of variance between methanolic and aqueous extracts confirms significant variation with p $>0.05$ (Ficus racemosa - 0.005, Aloe vera -0.0009 Cannabis sativa - 0.2459, Datura stramonium - 0.2356, and Calotropis gigantean - 0.0149) 


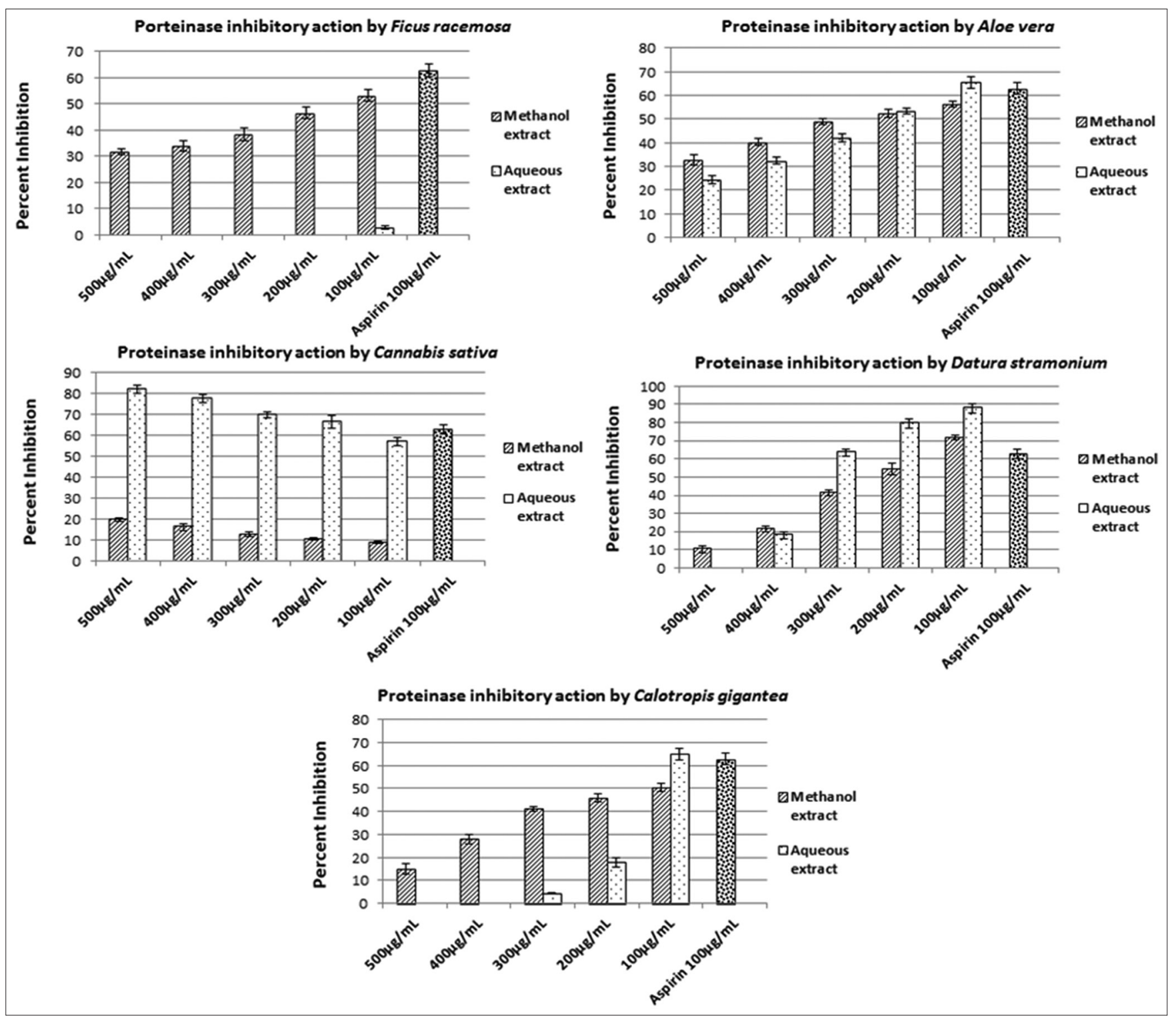

Fig. 2: Proteinase inhibitory action by different methanolic and aqueous extracts of medicinal plants. Two-way analysis of variance between methanolic and aqueous extracts confirms there is no significant variation with $p<0.05$ (Ficus racemosa - 0.0003, Aloe vera - 0.4931, Cannabis sativa - 2.26, Datura stramonium - 0.2311, and Calotropis gigantean - 0.1052)

albino rats. Antioxidant potential of $C$. gigantea was also reported by Iqbal et al. [23], affirming it to be a virtuous source of antioxidant. Leelaprakash and Mohan [24], also showed that Enicostemma axillare at a concentration range of $200-500 \mu \mathrm{g} / \mathrm{ml}$ protect hypotonicityinduced hemolysis of the erythrocyte membrane significantly against lysis induced by hypotonic solution. At the concentration of $500 \mu \mathrm{g} / \mathrm{ml}$, E. axillare exhibited maximum $75 \%$ of protection.

Anti-lipoxygenase activity was found to be maximum in methanolic extract of $F$. racemosa with $94.05 \pm 4.24 \%$. On the other hand, minimum activity was observed in aqueous extract of $A$. vera with $8.95 \pm 0.92 \%$ of inhibition, Fig. 5. F racemosa is reported as an effective antiinflammatory plant. The extract at 200 and $400 \mathrm{mg} / \mathrm{kg}$ doses has been found to have noteworthy anti-inflammatory activity on the experimental models [25]. Anoop and Bindu [26], who studied the effects of Syzygium zeylanicum leaf extracts on production, of leukotrienes, were estimated by the inhibition of lipoxygenase activity. The anti-inflammatory activity of $F$. racemosa extract was estimated on rat hind paw edema models; the results were found satisfactory with $79.26 \%$ in ethyl acetate extract and $77.65 \%$ in aqueous extract.
In another study anti-lipoxygenase activity using Momordica charantia extract and protein free $M$. charantia extract at different time intervals, $\mathrm{pH}$, temperature and different extract concentration was observed and found to be same for both the cases, confirming phytochemicals present in the extract are responsible for the activity, rather than protein [27].

Total antioxidant activity (established on the redox reactions between the antioxidant sample and the $\mathrm{KMnO}_{4}$ in acidic $\left(\mathrm{H}_{2} \mathrm{SO}_{4}\right)$ media, resulting in discoloration of $\mathrm{KMnO}_{4}$ ) was recorded highest in F. racemosa (4.38 $\pm 0.546 \mathrm{mM}$ equivalent of ascorbic acid/g tissue) at $500 \mu \mathrm{L}$ of sample used, while lowest in $A$. vera $(0.620 \pm 0.030 \mathrm{mM}$ equivalent of ascorbic acid/g tissue) at $500 \mu \mathrm{L}$ of sample used (Fig. 6). In a study by Johora et al. [28], the antioxidant activity of methanolic extract of $F$. racemosa was studied. It was found that the scavenging activity of $F$. racemosa from leaves and bark extracts was $48.54701 \%$ and $73.46154 \%$, respectively. A number of studies have been done on antioxidant properties from different plant part (mainly fruits) of F. racemosa are also reported [29,30]. 


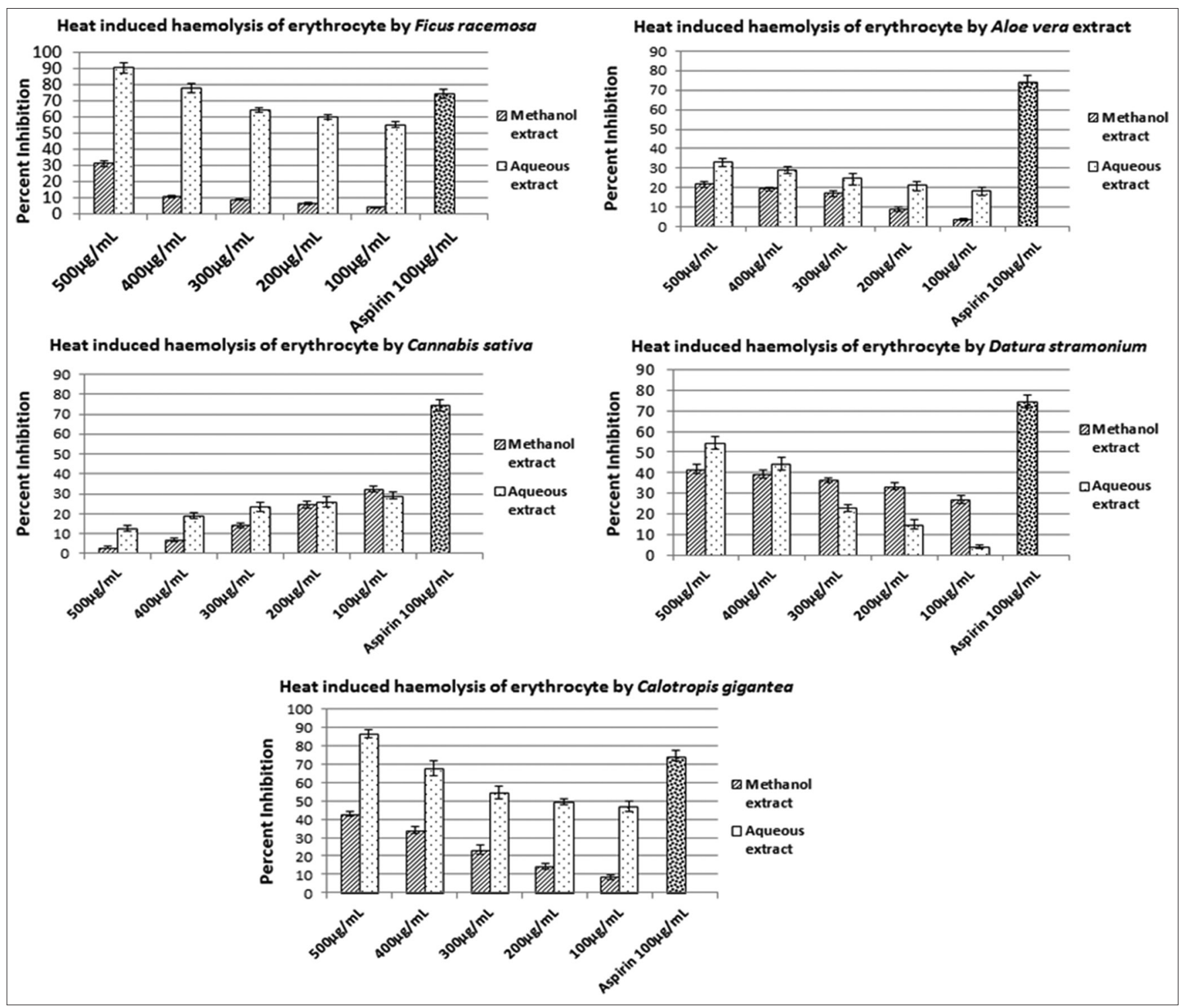

Fig. 3: Heat-induced hemolysis of erythrocyte by different methanolic and aqueous extracts of medicinal plants. Two-way analysis of variance between methanolic and aqueous extracts confirms there is no significant variation with $\mathbf{p}<0.05$ (Ficus racemosa - 3.44, Aloe vera - 0.0007, Cannabis sativa - 0.1102, Datura stramonium - 0.3445, and Calotropis gigantean - 7.30)

Antioxidant compounds originating from plants can reduce the formation of free radicals [31,32], and can lessen the diseases initiated by oxidative stress [33,34]. The flavonoids and phenolics compounds obtained from remedial herbs account for the antioxidative property of plants $[31,35,36]$ and thus act as an anti-inflammatory mediator [37]. Production of pro-inflammatory biomolecules such as nitric oxide and tumor necrosis factor (TNF- $\alpha$ ) can lessen inflammation. These inflammatory biomolecules respond with free radicals, which can be a cause of irreparable mutilation to cell membranes, causing tissue damage and cell death [38].

Furthermore, a strong positive correlation was observed between various anti-inflammatory activities and antioxidant activity (Table 1), which shows the relationship among the two factors. In a study by Chohan et al. [39] on culinary herbs, the relationship was found between their anti-inflammatory activity, polyphenol content, and antioxidant capacity. In the study, anti-inflammatory activity of cooked, uncooked, cooked and in vitro digested, and standardized $(30 \mathrm{mg} / \mathrm{mL})$ culinary herbs was evaluated by determining their influence on IL-8 release from Caco-2 cells and stimulated human peripheral blood lymphocytes.
The Trolox equivalent capacity and estimated total phenolic content of the herbs were also determined. The substantial correlations between Trolox equivalent capacity and phenolic content and anti-inflammatory activity suggest a possible contributory role of polyphenols to the antiinflammatory activity of the culinary herbs scrutinized, indicating a relationship between anti-inflammatory activity and antioxidant level.

\section{CONCLUSION}

Many of the analgesics drugs are known for their side-effects such as gastrointestinal and severe gastric disorders. Anti-inflammatory drugs comprise "biologicals" such as anticytokine therapies, which resist the activities of kinases and express a considerable decline in host resistance for infections. Due to health problems and side effects of existing anti-inflammatory drugs, naturally occurring anti-inflammatory supplements (plants) are now becoming popular. In recent years, various experimental techniques are employed to verify natural antioxidant and anti-inflammatory drugs from natural product resources. The present work is an attempt in the direction of anti-inflammatory drug development for several chronic inflammatory and allied diseases. It can be concluded that the plant species studied 

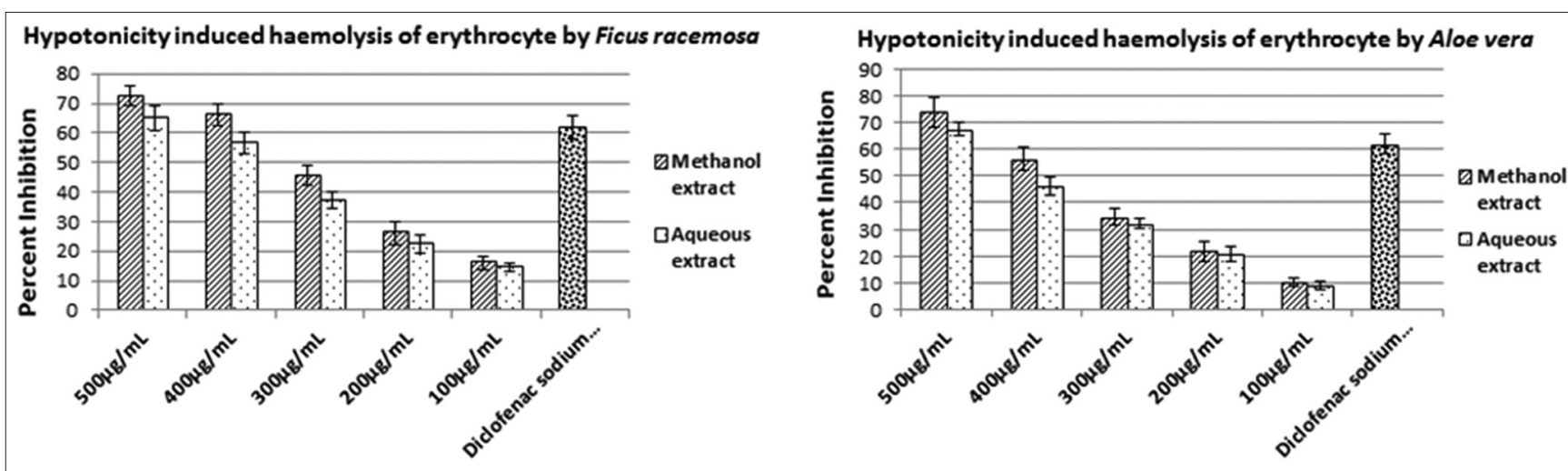

Hypotonicity induced haemolysis of erythrocyte by Cannabis sativa

Hypotonicity induced haemolysis of erythrocyte by Datura stramonium
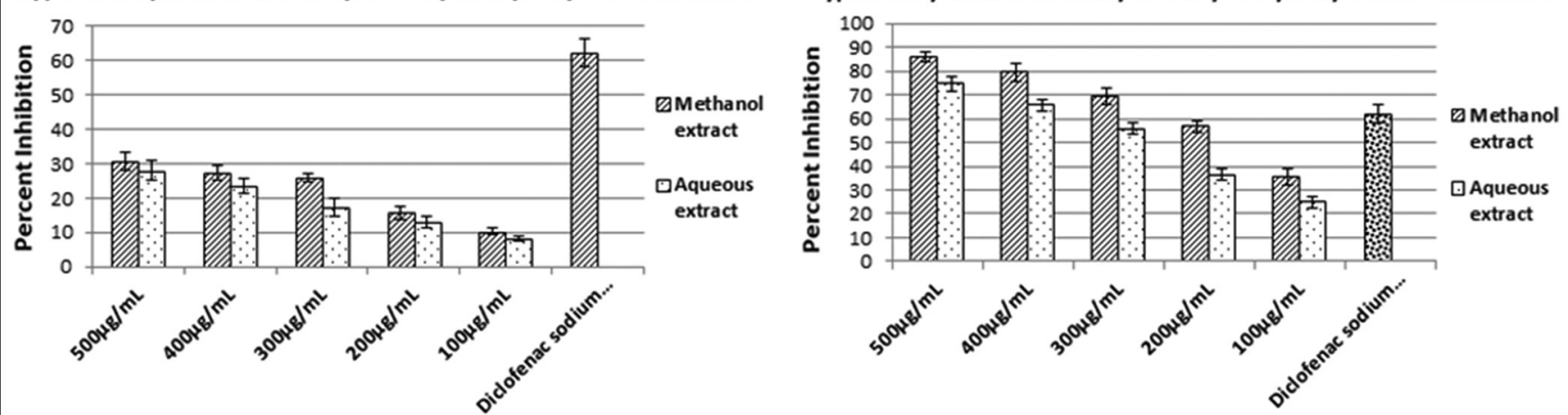

Hypotonicity induced haemolysis of erythrocyte by Calotropis gigantea

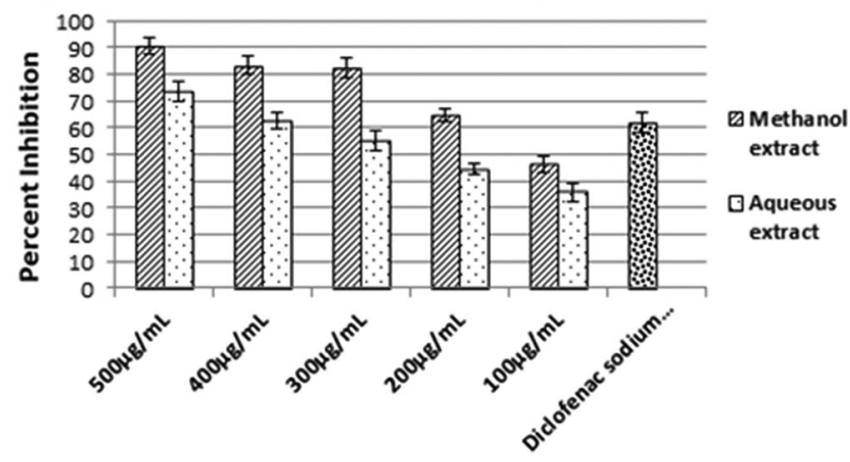

Fig. 4: Hypotonicity-induced hemolysis of erythrocytes by different methanolic and aqueous extracts of medicinal plants. Heat-induced hemolysis of erythrocyte by different methanolic and aqueous extracts of medicinal plants. Two-way analysis of variance between methanolic and aqueous extracts confirms significant variation with $\mathrm{p}>0.05$ (Ficus racemosa - 0.0143, Aloe vera - 0.0716, Cannabis sativa - 0.0267, Datura stramonium - 0.0012, and Calotropis gigantean - 0.0022)

Table 1: Correlation matrix between in vitro anti-inflammatory activity and antioxidant activity of plants used in the study

\begin{tabular}{|c|c|c|c|c|c|c|c|c|c|c|}
\hline \multirow{2}{*}{$\begin{array}{l}\text { Assessment } \\
\text { of in vitro } \\
\text { anti-inflammatory } \\
\text { activity }\end{array}$} & \multicolumn{2}{|c|}{$\begin{array}{l}\text { Antioxidant activity } \\
\text { of } F \text { racemosa }\end{array}$} & \multicolumn{2}{|c|}{$\begin{array}{l}\text { Antioxidant activity } \\
\text { of } A \text {. vera }\end{array}$} & \multicolumn{2}{|c|}{$\begin{array}{l}\text { Antioxidant activity } \\
\text { of } C \text {. sativa }\end{array}$} & \multicolumn{2}{|c|}{$\begin{array}{l}\text { Antioxidant activity } \\
\text { of } D \text {. stramonium }\end{array}$} & \multicolumn{2}{|c|}{$\begin{array}{l}\text { Antioxidant activity of } \\
\text { C. gigantea }\end{array}$} \\
\hline & $\begin{array}{l}\text { Methanolic } \\
\text { extract }\end{array}$ & $\begin{array}{l}\text { Aqueous } \\
\text { extract }\end{array}$ & $\begin{array}{l}\text { Methanolic } \\
\text { extract }\end{array}$ & $\begin{array}{l}\text { Aqueous } \\
\text { extract }\end{array}$ & $\begin{array}{l}\text { Methanolic } \\
\text { extract }\end{array}$ & $\begin{array}{l}\text { Aqueous } \\
\text { extract }\end{array}$ & $\begin{array}{l}\text { Methanolic } \\
\text { extract }\end{array}$ & $\begin{array}{l}\text { Aqueous } \\
\text { extract }\end{array}$ & $\begin{array}{l}\text { Methanolic } \\
\text { extract }\end{array}$ & $\begin{array}{l}\text { Aqueous } \\
\text { extract }\end{array}$ \\
\hline $\begin{array}{l}\text { Inhibition of albumin } \\
\text { denaturation }\end{array}$ & 0.9709 & 0.9540 & 0.9847 & 0.9912 & 0.9222 & 0.8883 & 0.9561 & 0.9352 & 0.8864 & 0.9642 \\
\hline Antiproteinase action & 0.9966 & 0.7851 & 0.9432 & 0.9973 & 0.9998 & 0.9660 & 0.9901 & 0.9320 & 0.9253 & 0.9115 \\
\hline $\begin{array}{l}\text { Heat-induced } \\
\text { hemolysis }\end{array}$ & 0.9041 & 0.9939 & 0.9300 & 0.9955 & 0.9970 & 0.9470 & 0.9362 & 0.9885 & 0.9955 & 0.9811 \\
\hline $\begin{array}{l}\text { Hypotonicity-induced } \\
\text { hemolysis }\end{array}$ & 0.9725 & 0.9853 & 0.9977 & 0.9977 & 0.9263 & 0.9898 & 0.9325 & 0.9659 & 0.8902 & 0.9888 \\
\hline $\begin{array}{l}\text { Anti-lipoxygenase } \\
\text { activity }\end{array}$ & 0.9097 & 0.9581 & 0.9930 & 0.9732 & 0.9972 & 0.9924 & 0.9694 & 0.9835 & 0.9054 & 0.9923 \\
\hline
\end{tabular}

F. racemosa: Ficus racemosa, A. vera: Aloe vera, C. sativa: Cannabis sativa, D. stramonium: Datura stramonium, C. gigantean: Calotropis gigantean 


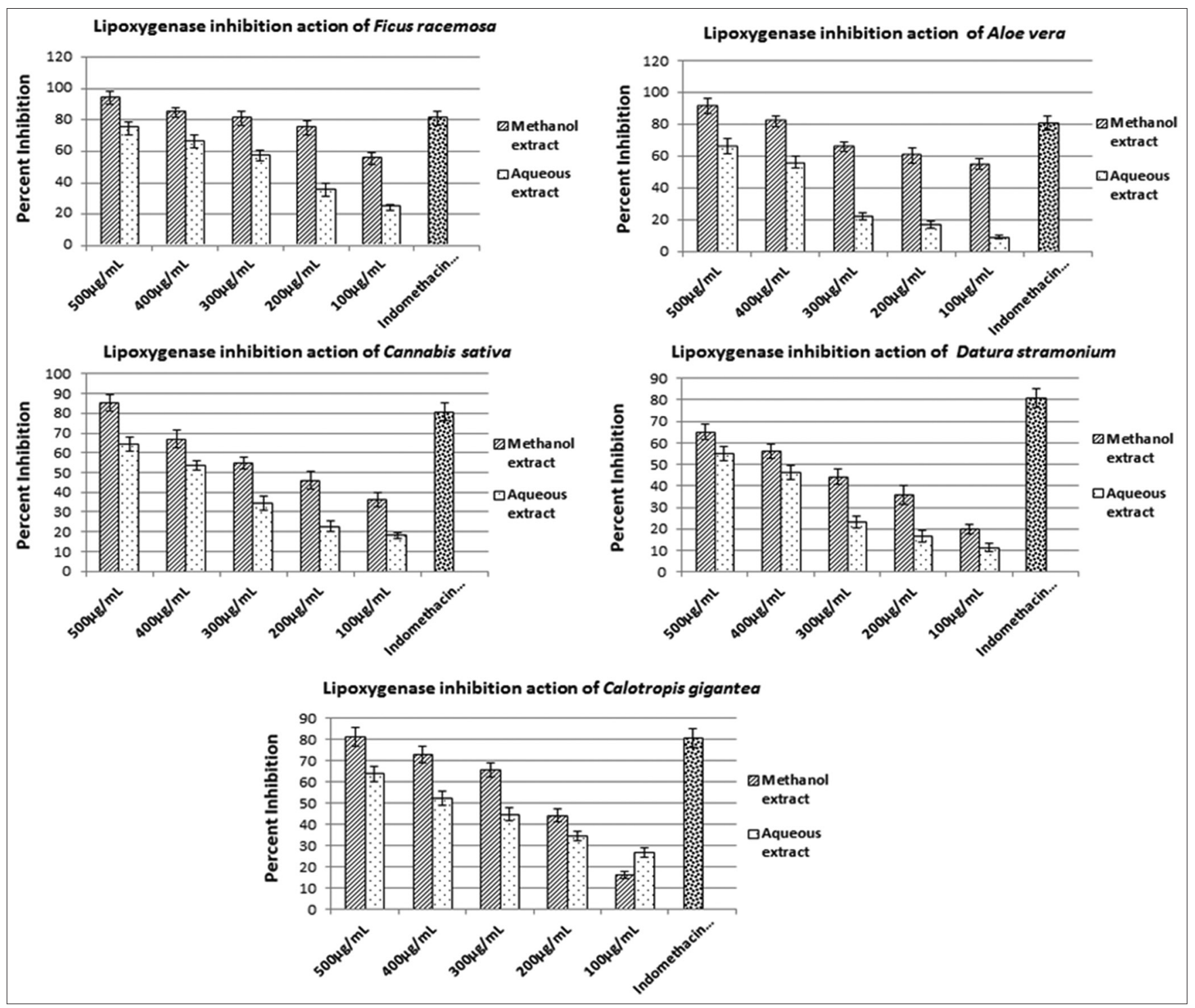

Fig. 5: Lipoxygenase inhibition action by different methanolic and aqueous extracts of medicinal plants. Two-way analysis of variance between methanolic and aqueous extracts confirms significant variation with p $>0.05$ (Ficus racemosa -0.0025 , Aloe vera -0.0013 , Cannabis sativa - 0.0003, Datura stramonium - 0.0065, and Calotropis gigantean - 0.1244)

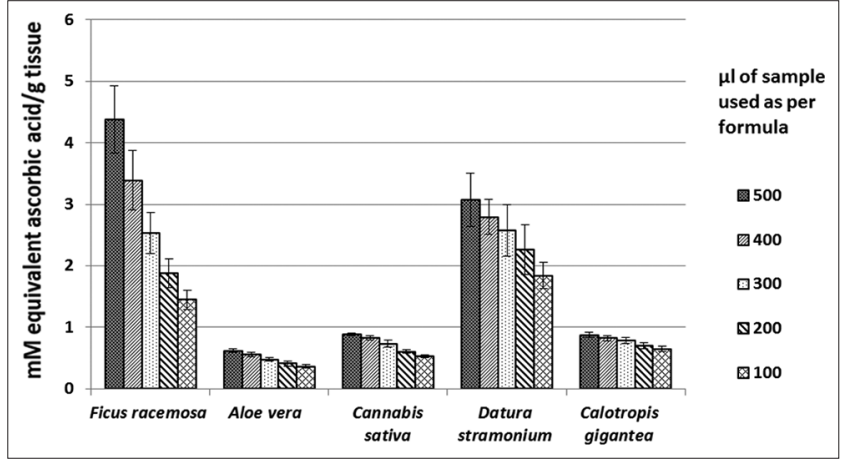

Fig. 6: Total antioxidant activity of different medicinal plants

possess significant anti-inflammatory and antioxidant activity. Their anti-inflammatory activity may be due to the antioxidants present in the plants. The correlation established between both the activities in the study establishes their relationship. Further work is required to fully elucidate the antioxidants responsible for this action and their mechanisms of action, for future herbal drug formulations.

\section{AUTHOR'S CONTRIBUTION}

All the authors contributed equally in planning, conductance of study, interpretation of results and writing.

\section{CONFLICTS OF INTERESTS}

Authors do not have any conflicts of interests to declare.

\section{REFERENCES}

1. Poyton RO, Ball KA, Castello PR. Mitochondrial generation of free radicals and hypoxic signaling. Trends Endocrinol Metab 2009;20:332- 40.

2. Reuter S, Gupta SC, Chaturvedi MM, Aggarwal BB. Oxidative stress, inflammation, and cancer: How are they linked? Free Radic Biol Med 2010;49:1603-16.

3. Coussens LM, Werb Z. Inflammation and cancer. Nature 2002:420:860- 7.

4. Hussain SP, Hofseth LJ, Harris CC. Radical causes of cancer. Nat Rev 
Cancer 2003;3:276-85.

5. Federico A, Morgillo F, Tuccillo C, Ciardiello F, Loguercio C. Chronic inflammation and oxidative stress in human carcinogenesis. Int $\mathrm{J}$ Cancer 2007;121:2381-6.

6. Hussain SP, Harris CC. Inflammation and cancer: An ancient link with novel potentials. Int J Cancer 2007;121:2373-80.

7. Tiwari P, Kumar B, Kaur M, Kaur G, Harleen K. Phytochemical screening and Extraction: A Review. Int Pharm Sci 2011;1:98-106.

8. Mizushima Y, Kobayashi M. Interaction of anti-inflammatory drugs with serum preoteins, especially with some biologically active proteins. J Pharm Pharmacol 1968;20:169-73.

9. Sakat S, Juvekar AR, Gambhire MN. In vitro antioxidant and antiinflammatory activity of methanol extract of Oxalis corniculata Linn. Int J Pharm Pharm Sci 2010;2:146-55.

10. Oyedepo OO, Femurewa AJ. Anti-protease and membrane stabilizing activities of extracts of Fagra zanthoxiloides, Olax subscorpioides and Tetrapleura tetraptera. Int J Pharmacong 1995;33:65-9.

11. Sadique J, Al-Rqobahs WA, Bughaith, EI Gindi AR. The bioactivity of certain medicinal plants on the stabilization of RBS membrane system. Fitoterapia 1989;60:525-32.

12. Shinde UA, Kulkarni KR, Phadke AS, Nair AM, Mungantiwar AA, Dikshit VJ, et al. Mast cell stabilizing and lipoxygenase inhibitory activity of Cedrus deodara (Roxb.) loud. Wood oil. Indian J Exp Biol 1999;37:258-61.

13. Azeem AK, Dilip C, Prasanth SS, Junise V, Hanan S. Anti-inflammatory activity of the glandular extracts of Thunnus alalunga. Asia Pac J Med 2010;3:412-20.

14. Cacig S, Szabo MR, Lupea AX, Ardelean A. Determination of the antioxidant activity of Ziziphus jujuba and Hydrangea incognita aqueous extracts. Studia Univ Vasile Goldis Seria St Vietii 2005;15:69- 72.

15. Iqbal MS, Ansari MI, Jafri S, Padmesh S, Ahmad I, Pandey B. Antioxidant potential of some medicinal plants (Ocimum sanctum, Azadirachta indica and Nigella sativa). Pharmacophore. Int Res J 2014;5:631-7.

16. Reshma, Arun KP, Brindha P. In vitro anti-inflammatory, antioxidant and nephroprotective studies on leaves of Aegle marmelos and Ocimum sanctum. Asian J Pharm Clin Res 2014;7: 121-9.

17. Shallangwa GA, Abdul-Hamidu A, Abba H, Dallatu YA, Bilham DT. In-vitro evaluation of aqueous extracts of Citurs sinensis, Aloe vera and their 1:1 extracts blend on protein denaturation during acute inflammation. J Biol Act Prod Nat 2013;3:295-302.

18. Duraid AA. Analgesiac, anti-inflammatory and antidiarrhoeal effects of Datura stramonium hydroalcoholic leaves extract in mice. Int J Res Rewv Appl Sci 2013;14:193-9.

19. Das SN, Chatterjee S. Long term toxicity study of ART-400. Indian Ind Med 1995;16:117-23.

20. Ramadevi M, Sivasubramanian N, Selvan AT, Prasad BS, Anbazhagan S. Screening of in vitro anti-inflammatory activity of Ficus virens bark. J Glob Trends Pharm Sci 2014;5:2034-6.

21. Govindappa M, Sravya SN, Poojashri MN, Sadananda TS, Chandrappa CP. Antimicrobial, antioxidant and in vitro antiinflammatory activity of ethanol extract and active phytochemical screening of Wedelia trilobata (L.) Hitchc. J Pharmacog Phytother 2011;3:43-51.
22. Saumya D, Sanjita D, Kumar DM, Saumya PB. Evaluation of antiinflammatory effect of Calotropis gigantea and Tridax procumbens on wistar albino rats. J Pharm Sci Res 2009;1:123-6.

23. Iqbal Z, Iqbal MS, Mishra K. Screening of antioxidant property in medicinal plants belonging to the family apocynaceae. Asian J Pharm Clin Res 2017;10:415-8.

24. Leelaprakash G, Mohan DS. In vitro anti-inflammatory activity of methanol extract of Enicostemma axillare. Int J Drug Dev Res 2011:3:189-96

25. Mandal SC, Maity TK, Das J, Saba BP, Pal M. Anti-inflammatory evaluation of Ficus racemosa Linn. Leaf extract. J Ethnopharmacol 2000;72:87-92.

26. Anoop MV, Bindu AR. In-vitro anti-inflammatory activity studies on Syzygium zeylanicum (L.) DC leaves. Int J Pharm Res Rev 2015;4:18- 27

27. Leelaprakash G, Caroline RJ, Mohan DS. In vitro anti-inflammatory activity of Momordica charantia by inhibition of lipoxygenase enzyme. Int J Pharm Pharm Sci 2012;4:148-52.

28. Johora S, Kabir AS, Abdul H, Abdullah M, Islam N, Abu R. Evaluation of the antioxidant activity of Ficus racemosa plant extracts from northwestern district of Bangladesh. J Life Earth Sci 2013;8:93-9.

29. Jahan IA, Nahar N, Mosihuzzaman M, Begum MR, Ali L, Khan AK, et al. Hypoglycaemic and antioxidant activities of Ficus racemosa Linn. fruits. Nat Prod Res 2009;23:399-408.

30. Hamid K, Sultana S, Urmi KF, Ullah MO, Zulfiker AH, Hossain MA. In vitro free radical scavenging and brine shrimp lithality bioassay of aqueous extract of Ficus racemosa seed. Jordan J Biol Sci 2011;4:51-4.

31. Cai Y, Luo Q, Sun M, Corke H. Antioxidant activity and phenolic compounds of 112 traditional Chinese medicinal plants associated with anticancer. Life Sci 2004;74:2157-84.

32. Dragland S, Senoo H, Wake K, Holte K, Blomhoff R. Several culinary and medicinal herbs are important sources of dietary antioxidants. J Nutr 2003;133:1286-90.

33. Akinmoladun AC, Obuotor EM, Farombi EO. Evaluation of antioxidant and free radical scavenging capacities of some Nigerian indigenous medicinal plants. J Med Food 2010;13:444-51.

34. Özen T, Çöllü Z, Korkmaz H. Antioxidant properties of Urtica pilulifera root, seed, flower, and leaf extract. J Med Food 2010;13:1224-31.

35. Kaur N, Kishore K. Antioxidant activity of methanolic extract of Phaseolus trilobus root powder. Int J Pharm Pharm Sci 2012;4:271-5.

36. Zhang L, Ravipati AS, Koyyalamudi SR, Jeong SC, Reddy N, Smith PT, et al. Antioxidant and anti-inflammatory activities of selected medicinal plants containing phenolic and flavonoid compounds. J Agric Food Chem 2011;59:12361-7.

37. Talhouk RS, Karam C, Fostok S, El-Jouni W, Barbour EK. Antiinflammatory bioactivities in plant extracts. J Med Food 2007;10:1-0.

38. Wang C, Levis GB, Lee EB, Levis WR, Lee DW, Kim BS, et al. Platycodin D and D3 isolated from the root of Platycodon grandiflorum modulate the production of nitric oxide and secretion of TNF-[alpha] in activated RAW 264.7 cells. Int J Immunopharmacol 2004;4:1039-49.

39. Chohan M, Naughton DP, Jones L, Opara EI. An investigation of the relationship between the anti-inflammatory activity, polyphenolic content, and antioxidant activities of cooked and in vitro digested culinary herbs. Oxid Med Cell Longev 2012;2012:627843, 9 